\title{
Very Feminine, Yet Unmercifully Intelligent. A Portrait of the Dutch Critic and Translator Elisabeth de Roos (1903-1981)
}

\author{
Elke Brems and Dorien De Man \\ University of Leuven, Belgium
}

\section{More Than a Muse}

Sometimes, Jane says, a woman can feel as if she betrays her man by losing her personality. The more she chooses that of her husband, the more she clings to him and the more she gets from him, the more she loses her sense of self. A woman gives herself very differently than a man usually imagines, but the worst moment arrives when she becomes aware that the woman whom she wants to be for him and the woman she is, are no longer the same. You can laugh about it, but it remains a terrifying deficit (du Perron 367) ${ }^{1}$.

In this excerpt from the autobiographical novel Het land van Herkomst (1935, Land of Origin) by the very influential Dutch author Charles Edgar du Perron (1899-1940), Jane, the wife of the main character, is talking. Jane struggles with the way the personality of a woman is compromised when she gives herself to a man. Although the words are ostensibly Jane's, they originate from the husband, who is telling the story as a first-person narrator. The fragment expresses the tension between autonomy and dependence, both in what is said by the woman as in the fact that what she says depends on what the narrator lets her say.

From the start, the novel has been read as autobiographical. The narrator/main character is the fictionalised alter ego of du Perron and Jane is du Perron's second wife, Elisabeth de Roos (1903-1981), whom he married in 1932. Although Jane is hardly present in the novel, critics agree that she played an important role in the background. The writer and critic Menno ter Braak even entitled his review of this book "Novel for Jane." Dutch specialist Ada Deprez reads the attitude of the narrator with respect to Jane as an attitude of "love and admiration that led to her enthronement as image and adversary of the honnête homme" (173). Yet, Elisabeth de Roos, who was the model for Jane, was more than Edgar du Perron's "image and adversary." She was a very productive and respected essayist, critic, journalist and translator. Ter Braak called her "a remarkable woman, very feminine and yet unmercifully intelligent" (in Hanssen 405). ${ }^{2}$ The contrast between "feminine" and "intelligent" that the quote implies ("yet", "remarkable") is significant for the Zeitgeist.

\footnotetext{
1 "Een vrouw, zegt Jane, kan soms voelen dat zij haar man verraadt door het verlies van haar persoonlikheid. Hoe sterker zij die van haar man kiest, hoe meer zij zich aan hem hecht, en hoe meer zij krijgt zelfs, hoe meer zij soms verliest wat haar in zichzelf interesseert. Een vrouw geeft zich heel anders dan de man het zich meestal voorstelt, maar het ergste moment komt als zij merkt dat de vrouw die zij geven wil en de vrouw die zij is, niet meer dezelfde zijn. Je kunt er dan wel om lachen, maar het blijft een angstig tekort" (du Perron 367). All translations are our own. The original text from letters, reviews, archival documents and literature can be found in the footnotes. Translated secondary literature or contemporary comments are not requoted in the original language.

2 “[...] een merkwaardige vrouw, buitengewoon vrouwelijk en toch ongenadig intelligent" (in Hanssen, 405).
} 
Jane is overestimated by the critics as a character in Het Land van Herkomst, she plays a marginal role in the book that more than anything focuses on the formation (the Bildung) of the first-person male narrator. In contrast, de Roos as a writer in her own right is fiercely underestimated by literary history. In her essay about de Roos, cultural historian Ansje Van Beusekom recapitulates her reputation as "the famous writer's dedicated widow" (269). She is usually called Bep (a confidential diminutive form of her first name) or Elisabeth du Perron-de Roos. The reduction of a woman writer to the muse or wife of a male writer is not unique and reminds us, for example, of the Dutch writer Stephanie Vetter. The at the time well-known and well-read Vetter married the Flemish author Ernest Claes in 1912. He was canonized as one of the most important and popular figures of Flemish literature while she is now, at best, remembered as his wife (Brems 16).

Elisabeth de Roos has largely been ignored by literary historians. ${ }^{3}$ Nevertheless, she played a major role in the literary scene. De Roos had enjoyed an exceptionally liberal and intellectual upbringing and studied French Literature at the Municipal University of Amsterdam. At the end of 1929, she travelled to London to write a doctoral thesis about the French writer Jacques Rivière. Between 1925 and 1930, de Roos wrote film and theatre reviews for a series of Dutch magazines and newspapers. ${ }^{4}$ By the end of the 1920s, her interest in film and theatre diminished in comparison to her interest in French and British literature. Even early on, she was able to gain a good reputation as an essayist, and as she began to make a name for herself, she could choose the magazines and newspapers for which she wanted to write (Mars 13).

De Roos belonged to the literary circles that evolved around Marsman, ter Braak and Vestdijk, the most influential authors of the Dutch interwar period (Andringa 515). According to ter Braak's biographer Léon Hanssen (2000), his criticism in the field of literature, intellectual life, film and theatre made him one of the Netherlands' most prominent vectors of culture during the interwar period and after. His close friend and colleague Charles Edgar du Perron was a very famous and also influential poet and author. Together with the Belgian author Roelants, they founded the journal with the highest profile in the Netherlands and in Flanders during the interwar period, called Forum (1932-1935). Even after its brief existence ended, this magazine remained an icon in Dutch literary history. The editors argued against aestheticism and fine writing and promoted the importance of the author's personality, which should be represented in a work of art in an honest and courageous manner (hence the term bonnête homme that Deprez used above). Alongside prose and poetry, Forum published many essays and polemics, which particularly accounted for the magazine's infamous reputation. Though it is hardly noticeable from the numerous publications on Forum, Elisabeth de Roos was one of the main essayists of the magazine.

Kees Snoek - who does not write about Forum, but about de Roos (an important nuance) - rates her among the core members of Forum and calls her an important comrade-in-arms of du

\footnotetext{
${ }^{3}$ Except for a thesis and article from Mars respectively from 1993 and 1995, two articles from Snoek (1995, 2003) and an article from Van Beusekom (2013) no attention has been paid to Elisabeth de Roos and none of these abovementioned focus on her translations.

${ }^{4}$ De Stem (on silent film!), Propria Cures, De Vrije Bladen, Filmliga, Rythme and Nieune Rotterdamsche Courant (NRC).
} 
Perron and ter Braak (210), which is confirmed in their correspondence. De Roos was involved with Forum from the very beginning and she wrote extensive essays for the magazine, including some elaborate pieces on Virginia Woolf that ter Braak called "hyper-intelligent," "excellent" and "beautiful" (to Elisabeth de Roos, 15 November 1931). Her essays "precisely launch those comments that have to be launched." $"$ The only remark that ter Braak made was that she writes "somewhat too intricately." Ter Braak urged de Roos to write for Forum: "Will you write for Forum often?" Snoek, the only critic who studied (a selection of) de Roos's essays in detail, reports that her essays and reviews have been written in a personal style, at times sharp and witty, other times exploring the correct formulation of the nuances that came to her mind. She felt the need for theoretical excursions much more so than her husband; certain terms and concepts that had been used in Forum are clarified in her texts (Snoek 210). She expresses the influential poetics of Forum in a more explicit and clearer manner than ter Braak and du Perron, who, however, are the only two writers that are identified in literary history with this poetics.

After marrying du Perron, de Roos had much less time to devote to her writing. After all, they made the agreement that she would do the chores so that he could devote himself to writing (Snoek 44). He continued to work on his novels, while de Roos not only did the housekeeping, but also became the family breadwinner. Lack of money became an important motive for her writing and led to a great many journalistic pieces and magazine articles, at the expense of more serious essays. Together - because of the money - they became correspondents in Paris for the evening paper Het Vaderland. Up to their departure to the Dutch East Indies (the current Indonesia) in October 1936, Snoek counts 112 articles written by de Roos as a Paris correspondent, while du Perron took on 10 articles; they wrote 2 articles together. Between 1932 and 1936, de Roos published about 40 reviews in the Nieuwe Rotterdamsche Courant (NRC), while she also wrote 17 articles for Forum, Groot Nederland and De Gids in the same period. In 1933, she wrote 17 Parisian letters for the Delftsche Courant, under the pseudonym Potomak (Snoek 44).

After the war - and after the death of her husband in 1940 from a heart condition - de Roos resumed essay writing in the newspaper Het Parool and in the new journal Libertinage, which started in 1948 and built on the basis that Forum had created in the 1930s. It was only after the death of her husband that de Roos made a name for herself as a translator. She started the translation of a voluminous work by Boris Souvarine on Stalin and Bolshevism in November 1939. This translation was published with du Perron's name as a translator on the cover page. However, we know from correspondence that the book had actually been translated by de Roos, but that the publisher wanted to keep this information secret because he wanted to utilise du Perron's prestige: “Bep translates Souvarine's Staline, and I run through the translation, but this is

\footnotetext{
5 "Ik heb het nu nauwkeurig overgelezen en ben tot de conclusie gekomen, dat beide stukken hyper-intelligent zijn en juist die opmerkingen lanceeren, die gelanceerd moesten worden.” (ter Braak to Elisabeth de Roos, 15 November 1931). All letters are to be found in the letterkundig Museum Den Haag (Elisabeth de Roos).

6 "Ik vind, dat je nog altijd iets te moeilijk schrijft." (ter Braak to Elisabeth de Roos, 15 November 1931).

7 “Zul je veel schrijven voor Forum?” (ter Braak to Elisabeth de Roos, 15 November 1931).
} 
a secret because the penny pincher Querido pays for my name, so that will be the one on the cover" (du Perron to Jan Greshoff, 25 February 1940). ${ }^{8}$

De Roos continued translating after the death of her husband and gained a very good reputation in the field. In the second half of the 1960s, she got invited by the Institute for Translators in Amsterdam, which had been open for a year at this point, to become a teacher in English-Dutch translation. Author Henk Romijn Meijer explains: "Bep du Perron translated from English and from French; she obtained a doctorate and had so much more to offer than the average teacher that we were only surprised that she had not been invited before" (204). Poet, translator and pioneer of translation studies James Holmes was also keen on recruiting de Roos for the institute (Romijn Meijer 204). Around the same time, de Roos collaborated on the Collected Works of both du Perron and ter Braak and gave lectures on the topic. After the death of both Forum men - who died on the same day in 1940 (a fact that strongly contributed to the creation of the myth around them) - she continued to propagate their reputation. She claimed for herself no active role in the mythology that grew up around ter Braak, du Perron and Forum, nor did literary history.

\section{Not Quite a Fellow}

Van Beusekom suggests that de Roos did not care for her own public voice (270). Ter Braak and du Perron were acutely aware of their strategic positions in the literary landscape, while de Roos seemed unconcerned about that. It has now been proven repeatedly that the movement of women toward the public space, and the literary field in particular, works out differently than men's. In the traditional gender discourse - which as a matter of fact not only influenced men, but also affected the self-image of female writers - femininity is associated with conservatism, obedience and care and masculinity with courage, intentional action and breaking norms. Given that gender is not a separate field, but a part of the social field (like class), and since the literary field is also part of the social field, gender always plays a role in literature as a structuring social factor (Reymenants 125). Innovation, for instance, was rated highly in the 20 th century as a property of a literary text, but was determined according to male criteria (Fenoulhet 185) and forms a historically contingent category, like originality.

Actors in the literary field of the Low Countries still constantly produced and reproduced this gender discourse (Reymenants 125) in the first half of the 20th century, which had a huge impact on the reception of (innovative) female writers. Their contribution to innovation - as in the case of de Roos - became a blind spot. At the very most, they are called images of the innovators, making it seem as if they imitate the innovation instead of operating it. The new poetics linked to Forum that de Roos propagated (and conceptualised!) had very masculine features: daring, courage, intellect and adventure were key words. This was at odds with the gender discourse, in which de Roos represented the antipode. Hence ter Braak's statement above that de Roos was feminine, yet intelligent.

\footnotetext{
8 "Bep vertaalt Staline van Souvarine, en ik kijk de vertaling na, maar dit is een geheim, want voor mijn naam wordt door den pingelsmous Querido betaald, dus die zal erop staan” (du Perron to Jan Greshoff, 25 February 1940).
} 
The main controversy ter Braak and du Perron triggered in the Netherlands's interwar period went down in history as "vorm of vent" (form or fellow): must a work of art first be aesthetically valuable (form) or should the author's personality (fellow) come first? According to Forum, the author must be a fellow: It is clear that in this highly gendered literary view of fellow-ism de Roos could not be seen, there was no actor-role for a woman available. Moreover, the genre of literary criticism and essay (which she practised) was a male bastion and, institutionally, that applied to most editorial boards as well, at least until the mid-20th century. Female authors "participate much less in social processes, strategies and conflicts of interest in the literary field. They rarely get mixed up in youth generations or other literary groups, in journal editorial boards, in debates or controversies" (Van Boven 244). Women were less educated, were rarely admitted to the public sphere, were not always allowed to seem bohemian, act unconventionally, visit bars or travel, etc. (Reymenants 125).

In recent years, research into poetics and institutions has focused on the influence of authors in establishing a certain image or canon (Van Boven 243). For gender studies, this approach provides more insight into the problematic relationship between female writers and literary history and the canon (Van Boven 244) and has resulted in research on intentional and strategic actions in the literary field. According to Stark, female writers and translators developed "techniques of self-denial [...] in order to erase traces of creative authorship, which would have upset the values of the predominantly male society they wished to comply with" (43). Although many women had an active professional life as cultural mediators, their literary ideas (e.g. of their characters or of themselves as authors) were often very conventional with regard to gender roles (Broomans 15). The Flemish writer Virginie Loveling, for instance, portrayed herself humbly and insecurely: "As the dominant nineteenth century cultural discourse about women held that they were emotional, intuitive and limited in their interests, Loveling literally portrayed herself that way" (Vandenbussche et al. 53). The Dutch Ina Boudier-Bakker committed herself to antipoetics: she explicitly wanted to have no notion of literature. Her writing was supposedly accidental or unintentional (Van Boven 250).

These authors internalised the existing images of femininity (Van Boven 250). Van Boven explains how these writers came to a solution in a situation where woman and artist are conflicting roles, "by elevating womanhood as an aim in itself and by putting it before the hardly compatible artistic calling" (250). Writing, i.e. working, women found themselves in a marginal social position. Their crossing of the traditional gender boundaries could only be accepted if it complied with their "feminine gifts in the family circle" or their "mission [...] in a higher maternity" (Dietsche Warande en Belfort 1919) ${ }^{9}$ and thus only if they wrote literature from that same viewpoint, as such collaborating "in the realisation of the ethical objectives of Literature" (Reymenants 124). Orthodoxy was the safest way for female writers and brought them the greatest chance of praise. Heterodoxy was only reserved for individuals with more economic, social and cultural capital (Reymenants 125), such as the Belgian author Marie Elisabeth Belpaire

\footnotetext{
9 "Liefst zien we U groeien en bloeien in de volheid uwer vrouwelijke gaven in den huiselijken kring; tenware gij, door God geroepen, uwe zending vervuldet in een hooger moederschap.” (O. p. S. Th. Lector P. Janssens, Dietsche Warande en Belfort 9 (1919): 811-812).
} 
or the Dutch author Henriette Roland Holst. Yet, even the orthodox writers showed a strong gender identity, which they use (consciously or not) to invade the literary field. The fact that these authors defended a certain imagery of womanhood paradoxically makes atypical women of them: they were women who played an opinionated role.

Moreover, from the 18th century onwards, it was only or mainly "within literary discourse that women were able to create their own space" or "a room of one's own" as Virginia Woolf called it, where they could express themselves (Wolf 17). Within writing, translating was a niche for many women in which they could channel their authorship: as a translator, you are indeed image and not pioneer. By translating, Stark explains, women could write without being exposed to the demands of independent authorship or social recognition (in Broomans 11). Some women knowingly preferred translation "because of its self-effacing nature. They insisted that it was more compatible than creative writing with what they considered to be their female role" (Stark 46). These women did not intend to adopt a masculine role; on the contrary. Nonetheless, they unintentionally slipped into literary space as professionals (Broomans 11). Translation was subordinate to writing, but it was professional and active. It led to an independent income, however limited, and provided access to the literary world (Woods 16).

\section{Working as a Translator}

De Roos gained a significant part of her income from translation in the first decade after du Perron's death. She consecutively translated Wuthering Heights by Emily Brontë (1941), Le père Goriot by Honoré de Balzac (1946), Jane Eyre by Charlotte Brontë (1947), La Chartreuse de Parme by Stendhal (1948), The Mill on the Floss by George Eliot (1950), Villette by Charlotte Brontë (1951) and Mina de Vanghel by Stendhal (1954). She also made translations of excerpts and essays written by Gide for an anthology. ${ }^{10}$ We know from correspondence that she argued with publishers regarding the translation of more contemporary authors including Malraux, Sartre and Camus. She tried to convince her publishers: "In recent months, I believe Camus arouses as much interest as does Sartre; people write about him everywhere" (to Contact, 18 November 1946). ${ }^{11}$ She also makes suggestions for translating children's books: "You still don't feel like having children's books translated? I have one at home by Nathaniel Hawthorne, stories from Greek mythology retold for children, which I think would make a nice illustrated edition, and it would give me a break to catch my breath before starting something so strenuous as Malraux" (to de Neve, 6 November 1946). ${ }^{12}$ Ultimately, she did not get to translate any of these authors. The quote above - and other fragments from letters - show that, for de Roos, translating was a difficult, arduous task, which she took very seriously. It certainly was not a pastime for her; she saw it as her job. Her correspondence shows that she read a lot and was well aware of

\footnotetext{
10 We haven't been able to verify whether this anthology was actually published.

11 "Ik geloof dat Camus hier de laatste maanden evenveel belangstelling wekt als Sartre; er wordt tenminste aan alle kanten over hem geschreven." (to Contact, 18 November 1946).

12 "Voelt u nog altijd niets voor kinderboeken? Ik heb in huis door Nathaniel Hawthorne voor kinderen navertelde verhalen uit de grieksche mythologie, waarvan ik denk dat een aardig geillustreerde uitgave te maken zou zijn, en het zou mij een ademhalingspauze geven voor ik aan zoo iets inspannends als Malraux begin." (to de Neve, 6 November 1946).
} 
contemporary European literature. Moreover, she was well versed in the business aspects of translation: she negotiated on translation rights, royalties and editorial policy. She also acted as a mentor to a younger translator, which is indicative of her expert status. ${ }^{13}$

De Roos chiefly translated for Contact, an antifascist publishing house founded in 1933 and led by Gilles de Neve and Chris Blom. In the first year of the war, Contact presented the series De Onsterfelijken (The Immortals). This series contained "masterpieces of all time, as far as these are interesting and readable for modern men and women" (in Kuitert 184), ${ }^{14}$ with work by the Brontë sisters, Andersen, Dostoevsky, De Coster, Reuter, Stendhal, Tolstoy, Gogol, Poe and Flaubert. Contact focused on the 19th century because the copyrights for these works had expired (Van Voorst, Nederlandse vitgeverijen 53). The series soon gained a very good reputation because the publisher only engaged the best translators, "that is connoisseurs of a particular author and in a position to write a serious introduction" (Boltendal 126). In practice, this mainly involved reputed Dutch, male writers such as Antoon Coolen, Arthur van Schendel, Simon Vestdijk, A. Roland Holst and Anton Van Duinkerken. That de Roos was offered a position as well confirms her prestige as an author at the time. The different volumes of the series were prefaced by the translator and artfully illustrated.

The selected works were "not so much intended for the general public [...] only the literary and traditionally representative values of the works seems to determine [the series'] choice" (Streven 1941). ${ }^{15}$ Many Contact books were banned and confiscated a year after the outbreak of the Second World War, mainly because of their alleged socialist and communist content. Works like Sherlock Holmes could not be published because they were "too British" (Kuitert 191). Yet, the relatively small publishing house developed steadily during World War II and worked at a profit (Jaeger 16). ${ }^{16}$ Quite exceptional is the fact that Contact also paid their translators even if the publication was banned. The series was initiated by the publishers to recruit authors who were out of work during the war for ideological reasons (for instance, the Jew Victor Van Vriesland) as translators. The publishers even ordered and paid for translations that they were certain would be banned. Those editions were then retained for after the war, but the translators got paid immediately (Jaeger 22). Kuitert reports that many manuscripts were ready to be published after the war. One of these was a translation by Elisabeth de Roos, but it is not clear which one. After World War II, Contact extended the series and issued various republications. The series eventually contained about forty titles. Seventeen works were published in Dutch translation for the first time, including De Chartreuse van Parma (The Charterhouse of Parma)

\footnotetext{
${ }^{13}$ E.g. "Ms. Ten Holt [...] is willing to translate l'Espoir under my supervision." From "Mej. Ten Holt [...] is bereid l'Espoir te vertalen onder mijn toezicht" (to Contact, 9 September 1946).

14 "Meesterwerken van alle tijden, voorzoover deze voor de moderne mensch interessant en leesbaar zijn." (in Kuitert 184).

15 "Minder bestemd voor het gewone publiek, richt zij zich tot de vakkundigen en de gespecialiseerde liefhebbers in de literatuur; alleen de literaire en traditioneel-representatieve waarde der werken lijkt haar keuze te bepalen." (Em. Janssen, Streven 9 (1941)).

${ }^{16}$ During the war, Contact was careful not to provoke. Its pragmatic attitude and amount of money made it able to live on and do a good job for writers in trouble. Moreover, Contact stated that "in these chaotic times" interest in "former centuries" was increasing (in Jaeger 15).
} 
and De Woeste Hoogte (Wuthering Heights), both translated by Elisabeth de Roos. Thus, these canonised works were introduced in the Netherlands in de Roos's version.

The translation of Wuthering Heights was the only volume in the series (part IV) that appeared during the Second World War. The translation was received as "a good translation [...] that has been taken care over and must be praised" (Leeuwarder Courant, 14 May 1948), ${ }^{17}$ at least, that is if the review indicates that it is reviewing a translation; often, that is not even stated (Het Vaderland, 3 August 1941 and Nieunsblad van het Noorden, 12 August 1967). Later, de Roos herself would call De Woeste Hoogte her best translation (to Contact, 15 March 1950). In 1939, the book had fallen prey to "the fierce tendency to transform great literature into film - for lack of original material" (De Tijd, 25 September 1947). It resulted in "a movie, which speculates fairly cheaply on a literary chef d'oeuvre" (De Tijd, 25 September 1947). ${ }^{18}$

In 1966, de Neve asked for de Roos's permission to include her translation, including the introduction, in Contact's newest series Classical Masterpieces. He suggested a print run of 7,000 copies and a fee of 150 guilders for the introduction and 500 guilders for the translation. It is not clear whether his proposal went through, but it gives us an idea of the fees and number of copies in that period. Between 1940 and 1949, de Roos should have received 1,250 guilders for prints and reprints of De Woeste Hoogte, 1,200 and 1,800 guilders for Jane Eyre's first print and reprints, 1,050 guilders for De Molen aan de Rivier, 1,200 guilders for De Chartreuse van Parma, 830 guilders for Vader Goriot and 500 guilders for the Gide Anthology. She collaborated on Wereldhistorie per Post (World History by Mai), a collection of letters of all times, under the leadership of Anton van Duinkerken, and received 33 guilders for her assistance. Today, the total amount would correspond to a purchasing power of 105,000 guilders or 47,600 euros (about 5,000 euros annually). ${ }^{19}$

In 1948, de Roos's translation of Stendhal's La Chartreuse de Parme was published in De Onsterfelijken. This "materialistic and sensual historical novel" was listed on the Index (De Tijd, 1 February 1949). ${ }^{20}$ This translation - "however impossible it [is] to preserve the charm of it all in a translation" - was gratefully received "for everything she [de Roos] managed to rescue and for the interesting introduction on the figure of Stendhal that she wrote" (Leeunarder Courant, 4 June

\footnotetext{
17 “[...] een goede vertaling [...] waaraan veel zorg is besteed en waarin veel te prijzen valt" (Leeunarder Courant, 14 May 1948).

18 "De woeste neiging om alle grote litteratuur in filmvormen om te zetten - bij gebrek aan oorspronkelijke stof", “[...] een filmwerk, dat vrij goedkoop speculeert op een litterair chef d'oeuvre." (De Tijd, 25 September 1947). This American movie (Wuthering Heights) was a Hollywood product by the well-known filmmaker William Wyler (19021981, director of Ben-Hur and The Best Years of Our Lives). In the same review in De Tijd, Wyler is described as "one of the most versatile directors of Hollywood, a veteran, a craftsman, but he is not at all impassioned, he is no poet." ("[...] een van de handigste regisseurs van Hollywood, een routinier, een vakman, maar alles behalve een bezielde, een dichter").

19 Today, that would correspond to $€ 6$ on average per guilder according to the calculator of the International Institute for Social History (see http://www.iisg.nl/hpw/calculate-nl.php, visited 5 May 2015).

20 "Materialistische en sensualistische historische roman" (De Tijd, 1 February 1949).
} 
1949). ${ }^{21}$ Contact called the introduction an "especially penetrating essay [that] to the reader, for his confrontation with Stendhal's intensity, will be a valuable antidote to the banality and hypocrisy of this time" (to de Roos, 8 January 1947). ${ }^{22}$ Around the same time, and with "great joy" on de Roos's behalf (to Contact, 15 June 1948), this novel was also turned into a movie and was not received very positively either. Moreover, a number of photos were used in the publication of the translation, taken from that same film. Unfortunately, these fit "just as well as solid tires for a racing bike - in the sense that they cumbersomely slow down the dazzling speed of the flow of ideas - or like fake pearls in a precious golden crown" (Leeuwarder Courant, 4 June 1949). ${ }^{23}$ In a letter from 1949, Contact assures de Roos that the pictures will be better adjusted to the book in the reprint of the Chartreuse.

De Roos's translation of Jane Eyre was also published with an introduction by the translator. De Roos wrote to de Neve that she incorporated Brontë's introduction into her own, but that she found the author's preface "rather moralising." She feared that such an introduction would "deter the rare reader who starts with the preface when reading the book" (24 March 1945). ${ }^{24}$ When the book was published, de Roos saw "with surprise [...] in the ad for Jane Eyre and on its cover [that] the book would be a disguised autobiography and that Charlotte Brontë describes her childhood experiences in it" (to Contact, 3 November 1947). ${ }^{25}$ According to de Roos, this was "completely untrue" and she pointed to the fact that she refutes this otherwise frequent misapprehension "in the very first sentence" of her introductory essay (to Contact, 3 November 1947). The publisher was quick to apologise for the misunderstanding. Unfortunately, even the cover version of the reprint had already been printed and carried the words "disguised biography." This error would be corrected in the third reprint (Contact to Elisabeth de Roos, 25 February 1948).

De Roos's correspondence with the Contact publishing house shows regular conflicts with regard to payments and struggles over the publication of du Perron's Collected Works. These are probably two reasons why de Roos would not translate anything else for Contact after Villette in 1951. In the 1950s, another publisher, De Bezige Bij, brought "a new series of small, fine

\footnotetext{
21 "Het is onmogelijk, de bekoring van dit alles in een vertaling te behouden, maar men dient Elisabeth de Roos toch dankbaar te zijn voor het vele dat zij nog wist te redden en voor de belangwekkende inleiding over de figuur van Stendhal, welke zij schreef." (Leeuwarder Courant, 4 June 1949).

22 "Het heeft mij verheugd dat U [...] dit bijzonder indringende essay geschreven hebt dat den lezer door diens confrontatie met Stendhal's intensiteit een waardevol antidotum zal zijn tegen de banaliteit en hypocrisie van dezen tijd." (to de Roos, 8 January 1947).

23 "Zij passen er even goed bij als massieve banden om een race-fiets - in dier voege, dat zij de tintelende vaart van de ideeënstroom telkens plomp vertragen - of als valse parels in een kostbare gouden kroon.” (Leeuwarder Courant, 4 June 1949). This Franco-Italian movie (La Chartreuse de Parme/La Certosa di Parma) was made in Italy in 1948. It was directed by French director and writer Christian-Jaque (1904-1994).

24 "Charlotte Brontë's voorrede voor Jane Eyre heb ik in mijn inleiding verwerkt; de hare was een beetje preekerig, en zou misschien de zeldzame lezer die begint met de voorrede, van de lectuur van het boek afschrikken.” (To de Neve, 24 maart 1945).

25 "Met verbazing heb ik èn in de advertentie voor Jane Eyre èn op het omslag gelezen dat het boek een "vermomde autobiografie" zou zijn en dat Charlotte Brontë er haar jeugdervaringen in beschrijft. Dat is n.l. geheel onjuist en staat des te gekker omdat de allereerste zin van mijn inleiding dit, overigens veel verspreide, misverstand al tegenspreekt." (to Contact, 3 November 1947).
} 
booklets" (Leeuwarder Courant, 26 July 1955) on the market, entitled Robijnenboekjes (Ruby Booklets). These "nice volumes, with very valuable content" (Leemwarder Courant, 26 July 1955) were a clear imitation of the German Insel-Bücherei. The well-established translators at work in this series "have already proven themselves some time ago" (Leeuwarder Courant, 26 July 1955). The publisher wanted to reach a large audience with this series, "but at the same time, it did not make too many concessions to popularity" (Leeuwarder Courant, 26 July 1955). ${ }^{26}$ As with De Onsterfelijken, the advantages of a series play a part: the volumes had a recognisable cover and the series could be advertised as a whole, which is cheaper (Van Voorst, Nederlandse vitgeverijen 158). Therefore, an individually purchased work from Contact, for instance, would cost 12.50 guilders, which was much more expensive in comparison to the series price (per volume, in series of three or ten volumes) (De Telegraaf, 22 October 1951). De Roos translated Stendhal's Mina de Vanghel for Robijnenboekjes.

\section{Prefaces and Poetics}

Female translators almost never assimilated all the roles that a cultural mediating translator could accept. They were seldom concerned with "the most prestigious forms of literary import, such as prefaces, conferences, chronicles and criticism" (Vandenbussche 141). They rarely wrote commentaries, essays or literary criticism in addition to translating. De Roos, by contrast, openly engaged in these tasks. Two of the introductions to her translations were also published separately as essays in the journal Libertinage. Among others, writer Clara Eggink was very enthusiastic about de Roos's introductions: "It should be emphasised that the introductions of Elisabeth de Roos add a value to her translations that goes beyond the intentions of the publisher. Magazine Editors, why do you leave this great essayist - do we happen to have too many of those in the Netherlands - in peace?" (Eggink 231). ${ }^{27}$ This shows that de Roos had not acquired a place as an essayist in the post-war literary landscape.

The five essays that de Roos published as a preface to her translations (Jane Eyre, Wuthering Heights, The Mill on the Floss, La Chartreuse de Parme and Père Goriot) show great erudition and literary substance. She embeds each work in the context of European literature and she is aware of the critical reception of the novels. She situates the novels, which are all 19th-century novels, in the most important literary currents of that time, namely romanticism and realism. Significant names from her frame of reference are Henry James, Charles Dickens, William Thackeray, Thomas Hardy, George Meredith and Virginia Woolf.

Three out of five of her essays elaborate on a female author, but she thematises that female authorship only indirectly. In her essay on George Eliot, she writes: "Let us, by all means, be aware that George Eliot [...] is not a forerunner of those novels about our family and

\footnotetext{
26 "Nieuwe reeks, kleine, fijne boekjes", “[...] aardige bandjes met een zeer waardevolle inhoud.”, “[...] omdat hier vertaalsters aan het werk geweest zijn, die hun sporen al lang verdiend hebben.”, “[...] maar tegelijk niet al te veel concessies aan de populariteit wil doen." (Leeuwarder Courant, 26 July 1955).

27 "Wel moet er de aandacht op gevestigd worden, dat de inleidingen aan de vertalingen van Elisabeth de Roos een waarde geven, die boven de bedoelingen van den uitgever uit moeten gaan. Tijdschriftredacties, waarom laat gij deze zeer goede essayiste - hebben wij die soms te veel in Nederland - met rust?" (Eggink 231).
} 
neighbours that here we have come to call ladies' novelettes. It is far too impossible for her, one who always feels the need to travel from the individual on to the general, to switch off her intelligence for that" (Eliot XI) ${ }^{28}$ With that, de Roos casually criticises a familiar genre of Dutch novel-writing from the first half of the 20th century. The criticism of these ladies' novelettes corresponds to the Forum-circle's range of ideas. In 1934, Menno ter Braak published a sarcastic, critical essay entitled "Le chemin des dames." In his essay, he denounces the novels written by Dutch women that at the time were very popular and according to him "as numerous as the sand of the sea" (204). According to Andringa, "the essay is part of a certain tendency in mainstream literary criticism since the 1920s to combat the rather popular women's novels as artistically inferior" (26).

De Roos does not appreciate novels that only describe their own (domestic) environment. That is why she prefers novels such as Wuthering Heights: she believes that Emily Brontë "apparently did not feel the same need, as do almost all female authors, to describe or criticise the reality in which she exists and suffered" (Brönte, De woeste hoogte XIV). ${ }^{29}$ De Roos mocks the cramped connection of female writers to their "home" in many ladies' novels. With reference to Charlotte Brontë's Jane Eyre, de Roos notes that the author actually thematises this woman - bouse relationship in her book: 'in Charlotte Brontë's time, this was still an unspoiled ingredient for a writer, which has now, after hundreds of warmly pitched, snugly artistic, cosy, faint lighted tea table novels, become impossible" (Brönte, Jane Eyre X).$^{30}$ Through Charlotte Brontë, de Roos jeers at what was known as the ladies' novel in the Netherlands. She does so by imitating their language: assembling adjectives based on an opposition to create a pseudo-mysterious atmosphere. In a footnote she adds that apparently, the intellect and sophistication of a Virginia Woolf were needed to create a new relationship between women and objects. Intellect is a key word for de Roos: this is also what appeals to her in George Eliot. According to de Roos, Eliot was “the fairly rare figure, an 'intellectual woman,' in her day" (Eliot V). ${ }^{31}$

In their essay Literatuuropvattingen als denkstijl (Literary summaries as a school of thought) in the book De productie van literatuur (The production of literature), Dorleijn and Van den Akker make some interesting comments on the introduction of new paradigms in the literary field. They emphasise that new standards are laid down in rather identical terms and the importance of catchwords with that. "Reproduction - the way standards spread - is largely perceptible by looking at the signal words, more or less fixed phrases, stock lines of argument." That proves "that individual spokespersons participate in a collective jargon" (92-94). It is conspicuous in the introductions that de Roos uses Forum's catchwords (a magazine that in fact introduced a new paradigm).

\footnotetext{
28 "Laat men echter vooral niet denken dat George Eliot [...] een voorloopster is van die romans over onze familie en buren, die wij hier in Holland damesromans zijn gaan noemen. Daarvoor was het haar veel te onmogelijk om haar intelligentie uit te schakelen, die altijd de behoefte had van het individuele naar het algemene te gaan." (in Eliot XI). 29 "[...] blijkbaar helemaal niet die behoefte had van bijna alle vrouwelijke auteurs, om de realiteit waarin zij bestaan en geleden hebben, te beschrijven of te kritiseren" (in Brönte, De woeste hoogte XIV).

30 "In Charlotte Brontë's tijd was dit nog een onbedorven ingrediënt voor een schrijfster; nu is het, na honderden warm-tonige, knus-artistieke, gezellig gedempt-verlichte vertrekken uit de theetafelroman, onmogelijk geworden." (Brönte, Jane Eyre X).

31 “die in haar dagen betrekkelijk zeldzame figuur, een 'intellectuele vrouw" (Eliot V).
} 
A term that is related to the widely used intellect is lucidity: this term is central in de Roos's views on literature and is reflected in her essays. From reading her essays, a clear Forumian conception emerges, that manifests itself in the use of certain key words. She poses melodrama and sentimentality opposite intellect and lucidity. She appreciates Stendhal very much because of his intellect; she reproaches de Balzac for his sentimental rhetoric. In addition, intensity and brightness, and even ruthlessness are important. Facing those are dullness and inbibition.

De Roos regrets George Eliot's reasonableness and conventionality and the fact that she is not so fierce and revolutionary, while Emily Brontë, for example, writes much more fundamentally and unconventionally and is never obstructed by clichés and social inhibitions. The problem with Eliot, according to de Roos, is that the psychology of the characters clings too tightly to ethical concerns: de Roos argues (a hundred years later, of course!) in favour of a psychology that is free of ethics, with which she means that the choices made by a character, for instance, should not be explained by moral or religious considerations, but by the twists of the human psyche.

Psychological insight appears to be a very important criterion for de Roos, even though she does not use the term. She sees that kind of insight as a sign of modernity. She is not fond of authors (e.g. Balzac) who write too much in figures or prototypes since "we have been cured of thinking in global and unilateral characters" (Balzac XII). ${ }^{32}$

That interest in psychology and insight into human nature emerges from her essays in yet another way: she pays very close attention to the figure of the author himself. ${ }^{33}$ She explicitly states a few times that she certainly does not want to give an autobiographical reading of the book and she does not do that. However, she clearly believes the personality of the author is of great importance. This focus on the author fits into the Forumian idea that artists should be personalities and that that should be reflected in their oeuvres. She does not read the novels as an autobiography, but as a self-portrait. The difference lies in the fact that a novel is not a representation of facts and events of the author's life, but the display of one's intellect, honest opinion and human weaknesses. Here she uses the buzzword accent: a novel should have accent, must be "typical" of a particular author, carry the author's colour and tone. She prefers Stendhal above de Balzac because of his partis pris.

\section{The Translation of Wuthering Heights}

The first published translation by Elisabeth de Roos (next to Souvarine's Staline) was Emily Brontë's Wuthering Heights in 1941. We made a brief comparison of de Roos's translation with two other Dutch translations that came out almost simultaneously (which is remarkable in itself). None of the three translations mention the edition of the original on which the translators have

\footnotetext{
32 "Wij hebben afgeleerd om in globale en eenzijdige typen te denken." (Balzac XII).

33 She also suggested to Contact to translate "an important psychological work" titled Self-Analysis by Dr. Karen Horney (5 November 1946).
} 
based their work. We used the 1985 edition of the Penguin Classics. In addition to the translation by de Roos, there is a translation by the unknown J. Leclée from 1945 (published by De Sleutel, Antwerp) and of the Flemish author Karel Jonckheere from 1942 (published by De Nederlandsche Boekhanded), both published in Flanders.

When we first take a look at the title of the book, we immediately see that Elisabeth de Roos stayed closest to the source text by translating Wuthering Heights into Woeste Hoogte (literally Fierce Height). She does not retain the plural, but she does keep the initials $W$ and $H$. Jonckheere opts for Eenzamen op het Waaihof (literally Loners in Windy Yard) which is slightly more explanatory and brings the characters into prominence and not the place. He also immediately labels the characters as lonely, which directs the reader. By choosing Waaihof as a place-name, he keeps the letters $W$ and $H$ as well. In the text, where Brontë explicates the name of $W$ uthering Heights, Jonckheere has to resort to mentioning the English name alongside the Dutch one. Leclée chose the title Barre Hoogte (literally Rigorous Height).

Later, in 1956, de Roos received a Prisma booklet of a translation of Wuthering Heights, entitled De Woeste Hoogte (The Fierce Height, a definite article is added). The translator is called K. (probably Karel) Luberti. De Roos wonders whether "one may merely adopt a title that is not a literal translation of the original?" (to de Neve, 28 August 1956). ${ }^{34}$ After having the text spotchecked, however, she sees no further reason for speaking of plagiarism. De Neve, conversely, would not let the matter drop. His publishing house, Contact, continues to object to "the reproduction of the title of our publication" and asks Prisma to choose another title for republication (3 January 1957). Prisma replies that such similarities are inevitable and that "Woest and Hoogte are the standard dictionary translations for Wuthering and Heights." They call it a literal translation, which is nonsense if you look at the other translations. More relevant is their commercially tinged remark that "names such as [...] De Woeste Hoogte [...] have become much more of a general term instead of a literary creation, which must be used in all decency by everyone to avoid confusion among the public" (quoted in a letter from de Neve to de Roos, 3 September 1956). ${ }^{35}$ With that, they actually declare that De Woeste Hoogte has become the established title in Dutch for Wuthering Heights and that it is not commercially viable to title the book differently. De Neve is unsatisfied with this answer and wants to start proceedings against Prisma or to bring the case into the open. The next Prisma editions are entitled Woeste Hoogten ${ }^{36}$ (Fierce Heights), another title, but with a slight difference (plural rather than singular).

De Roos, incidentally, shows her self-consciousness as a translator when she says the following about the Prisma translation: it is "not bad either, in my opinion; however, I do have the feeling that I put more effort into mine and it therefore has a stronger voice - although, after

\footnotetext{
34 "Ik vraag mij af of men zomaar een titel mag overnemen die niet een letterlijke vertaling van de oorspronkelijke is?" (to de Neve, 28 August 1956).

35 "Immers namen als [...] De Woeste Hoogte zijn in plaats van een litteraire schepping veel meer een algemene aanduiding (zijn) geworden, welke fatsoenshalve ter voorkoming van verwarring bij het publiek door een ieder moet worden gebruikt." (quoted in a letter from de Neve to de Roos, 3 September 1956).

${ }^{36}$ Brontë, Emily: Woeste Hoogten, Prisma, 1st edition in 1956 - 11th edition in 1977. Translation of Wuthering Heights (1847) by K. (probably Karel) Luberti.
} 
so much time, there are things that I would like to change a little as well" (to de Neve, 24 September 1956). ${ }^{37}$

De Roos (like Leclée) preserves names such as Thrushcross Grange, which are hard to pronounce in Dutch. Jonckheere translates the name rather literally into Lijsterkrmishoeve. Various fragments of the translation show that de Roos remains closest to the source in comparison to the other two translators (Jonckheere's translation is the most goal-oriented). De Roos translates the word misanthropist by the loanword misanthroop, while the others translate it as menschenhater (literally hater of people). When the dogs are called, it says in English: "Hey Gnasher, hey dog, hey Wolf." Jonckheere and Leclée translate the first name (which again is difficult to pronounce in Dutch) as Knars (Crunch) and Knawwer (Munch) respectively, while de Roos preserves Gnasher. She also used the same exclamation word "Hey" (Hei) while the others choose the Dutch equivalents $J u$ (Gee) and Hier (Here).

De Roos's strong orientation to the source language is also evident from the fact that her translation does not necessarily make things more explicit. When the dog Juno appears in the story for the second time, it is assumed in English that the reader knows that Juno is a dog: it just says "the villain Juno." De Roos translates this almost literally ("de kwaadaardige Juno"), while the other translators take the reader by the hand by further indicating that a dog is involved (Jonckheere: "de leelijke hondenmoeder Juno" as in "the ugly bitch dog Juno" and Leclée: "de rekel Juno," literally "the dog Juno"). De Roos takes no part in the general tendency to simplify either. A phrase such as "in the interval of swallowing one cup of tea and receiving another" she translates extensively as "tusschen het opdrinken van één kop thee en het aannemen van een tweeden", while Jonckheere summarises the scene to "tusschen twee tassen thee in" ("in between two cups of tea").

When Nelly sings a Scottish ballad as a lullaby for Hareton, only de Roos chose to retain both rhyme and content to reproduce the atmosphere. The cited lines are: "It was far in the night, and the bairnies grat / The mither beneath the mools heard that." Jonckheere makes an innocent song out of it depicting a babbling child and a mouse that cannot sleep. Leclée lets the children cry, but reassuringly adds that the Mother in heaven hears their lament. Only de Roos preserves the ominous atmosphere portraying the children who are lost and the mother lying six feet under.

A final example of de Roos's remarkable fidelity to the source text is her dealing with Joseph's Yorkshire dialect, for example, “they's nobutt t' missis, and shoo'll nut oppen 't". De Roos explicitly opts for an anomalous spelling, pronunciation and vocabulary ("Allinnig mevrouw, en die duut niet los"). Jonckheere adapts the standard language just a little bit ("Niemand anders dan de bazinne en ze gaat niet opendoen") and Leclée does not use dialect,

\footnotetext{
${ }^{37}$ It is "m.i. ook niet slecht; wel heb ik het gevoel dat ik destijds meer in de mijne geleefd heb en dat die daardoor meer 'stem" heeft - hoewel er na zoveel tijd toch ook wel dingen in zijn die ik nu een beetje anders zou willen doen." (to de Neve, 24 September 1956).
} 
but only standard language to translate Joseph's words ("Alleen maar mevrouw en die doet niet open").

From these findings, we can draw preliminary conclusions with respect to de Roos's translation poetics. She is source-oriented and does not opt for simplification or explicit formulations. Her thorough knowledge of and appreciation for the author and the text may have played a role in this.

\section{Conclusion}

Elisabeth de Roos was an exceptional figure in several ways and she produced an impressive oeuvre. Yet she was a victim of marginalisation: as a woman, as a wife, as a writer and as a translator. De Roos has been left out of all Dutch literary history books (e.g. Ruiter and Smulders (1996), Anbeek (1999) and Brems (2009)). This is all the more striking because her husband, Edgar du Perron, and their friend, Menno ter Braak, are always assigned a major role in such overviews, particularly with regard to their work for the journal Forum, in which de Roos, too, was a very active, productive and esteemed essay writer. She not only shared the poetics and world view of Forum, she also helped to conceptualise and apply them. De Roos herself never claimed an important role in the history of the journal, although she was active as a mediator and legislator of Forum's ideology after the war by giving talks about ter Braak en du Perron and by taking care of the publication of their collected works. Hanssen explains how du Perron requested de Roos's "attention and self-sacrifice [...] that she summoned naturally for his own writing and life clumsiness." It is beyond doubt, Hanssen adds, "that this talent of great significance and purity was suffocated or anyhow ended up on the wrong track as a result of this constellation" (141).

When de Roos died in 1981, the Dutch author Van Galen Last wrote in an obituary in a national newspaper that it was a missed opportunity for the Netherlands that de Roos's essays were never collected, since the genre had never been so skilfully practiced as by de Roos. According to the author, de Roos wrote the most beautiful things ever written in the Netherlands about, among others, Woolf, the Brontë sisters, Stendhal, Beckett, Borges and Gombrowicz. The last two authors were introduced in the Netherlands by de Roos.

It is clear that de Roos was exceptionally good in the essay and criticism genres (including prefaces) and that she was an important cultural mediator, introducing, translating and analysing many major foreign authors for a Dutch readership. From her life's story, we can deduce that lack of money and time forced her to write a great many journalistic pieces and magazine articles at the expense of more serious essays. In the first decade after the war, being a single mother, she earned her living primarily as a translator. Her excellent reputation as a translator finally led to her job as a lecturer at the Institute for Translators in Amsterdam.

As a translator, de Roos was very professional. Not only did she spend a lot of time and effort on the translation itself, she also wrote extensive prefaces. In these introductory essays, she exposed her impressive literary substance and her preference for novels of intellect and courage 
that reveal an author who is fierce and dares to take a stand. She also showed herself an adversary of ladies' novels. Our analysis of de Roos's translation of Wuthering Heights shows that she is a fierce translator herself: she doesn't simplify or explain, she doesn't try to reduce the distance in space and time between the novel and the reader by mediating; she keeps a distance and counts on the intellect of her reader. 


\section{REFERENCES}

Anbeek, Ton. Geschiedenis van de literatuur in Nederland, 1885-1985. Amsterdam/Antwerpen: De Arbeiderspers, 1999. Print.

Andringa, Els. "Penetrating the Dutch Polysystem: The Reception of Virginia Woolf, 1920 2000.” Poetics Today 27.3 (2006): 501-568. Print.

Balzac, Honoré de. Vader Goriot. Vertaald en ingeleid door Elisabeth de Roos. Amsterdam: Contact, 1946. Print.

Boltendal, Rudi. Boekmakers. Portretten van uitgevers. Amsterdam: Moussault, 1965. Print.

Brems, Elke. "Van ondergeschikt belang? Stephanie Vetter in de Vlaamse literatuur." Tijdschrift voor genderstudies 4 (2003): 16-26. Print.

Brems, Hugo. Altijd weer vogels die nesten beginnen. Amsterdam: Bert Bakker, 2009. Print.

Brönte, Charlotte. Jane Eyre. Vertaald en ingeleid door Elisabeth de Roos. Amsterdam: Contact, 1947. Print.

—. Villette. Vertaald en ingeleid door Elisabeth de Roos en C.J. Kelk. Amsterdam: De Bezige Bij, 1951. Print.

Brönte, Emily. De Woeste Hoogte. Vertaald en ingeleid door Elisabeth de Roos. Amsterdam: Contact, 1941. Print.

-. Eenzamen op het Waaihof. Vertaald door Karel Jonckheere. Antwerpen: De Nederlandsche Boekhandel, 1942. Print.

—. De Barre Hoogte. Vertaald door J. Leclée. Antwerpen: De Sleutel, 1945. Print.

Broomans, Petra. "Introduction: Women as Transmitters of Ideas." From Darwin to Weil. Women as Transmitters of Ideas. Ed. Petra Broomans. Groningen: Barkhuis, 2009. 1-20. Print.

Calis, Piet. Het elektrisch bestaan: schrijvers en tijdschriften tussen 1949 en 1951. Amsterdam: Meulenhoff, 2001. Print.

Deprez, Ada. E. du Perron. Zijn leven en zijn werk. Brussel/Den Haag: Uitgeversmaatschappij A. Manteau, 1960. Print.

Dorleijn, Gillis and Wiljan van den Akker. "Literatuuropvattingen als denkstijl." De productie van literatuur. Het literaire veld in Nederland 1800-2000. Nijmegen: Vantilt, 2006. 91-122. Print. 
Du Perron, Edgard. Het land van herkomst. Amsterdam: G.A. van Oorschot, 1962. Print.

Eggels, Hanneke. "Een literair onbehagen: de muze weigert model te staan." Hollands Maandblad Amsterdam 43:2 (2001-2002): 20-24.

Eliot, George. De molen aan de rivier. Vertaald en ingeleid door Elisabeth de Roos. Amsterdam: Contact, 1950. Print.

Fenoulhet, Jane. Making the Personal Political: Dutch Women Writers 1919-1970. London: Modern Humanities Research Association and Maney Publishing, 2007. Print.

Hanssen, Léon. Want alle verlies is winst: Menno ter Braak 1902-1930. Amsterdam: Balans, 2000. Print.

-. Een misverstand om in te geloven. De poëzie van M. Vasalis. Amsterdam: Atheneum-Polak \& Van Gennep, 2007. Print.

Jaeger, Toef. Uitgeverij Contact. 1933-2008. Een kleine geschiedenis. Amsterdam: Contact, 2007. Print.

Kuitert, Lisa. "Talrijke uitgaven in voorbereiding. Uitgeverij Contact." Inktpatronen. De Tweede Wereldoorlog en het boekbedrijf in Nederland en Vlaanderen. Ed. Hans Renders et al., Amsterdam; De Bezige Bij, 2006. Print.

Mars, Petra. Elisabeth de Roos: schriffster in de schaduw. Amsterdam: Universiteit van Amsterdam, 1993. Print.

—. "Schrijfster in de Schaduw." Cahiers voor een Lezer 3 (1995): 7-14. Print.

Reymenants, Geraldine. "Catholicism as a Stepping Stone to Authorship: The Contribution of Women to the Flemish Catholic Periodical 'Dietsche Warande en Belfort'." From Darwin to Weil. Women as Transmitters of Ideas. Ed. Petra Broomans, Groningen: Barkhuis, 2009. 121-137. Print.

Romijn Meijer, Henk. Een krans rozen en een zakedoek. Amsterdam: Meulenhoff, 1988. Print.

Ruiter, Frans and Wilbert Smulders. Literatuur en moderniteit in Nederland 1840-1990. Amsterdam/Antwerpen: De Arbeiderspers, 1996. Print.

Snoek, Kees. "De kennis van het menselijk hart. Elisabeth de Roos als criticus." Forum der letteren 1995 (1995): 201-211. Print.

—. “'Zooveel mogelijk moet alles tot een parijsch evenement(je) opgeblazen worden!' De Parijse brieven van Elisabeth de Roos." Zacht Lawijd 3 (2003-2004): 39-58. Print. 
Snoek, Kees. E. Du Perron: het leven van een smalle mens. Amsterdam: Nijgh \& Van Ditmar, 2005. Print.

Stark, Susanne. "Bebind Inverted Commas": Translation and Anglo-German Cultural Relations in the Nineteenth Century. Clevedon: Multilingual matters: 1999. Topics in Translation, 15. Print.

Stendhal. De Chartreuse van Parma. Vertaald en ingeleid door Elisabeth de Roos. Amsterdam: Contact, 1941. Print.

- Mina de Vanghel. Vertaald en ingeleid door Elisabeth de Roos. Amsterdam: De Bezige Bij, 1954. Print.

ter Braak, Menno. "Le chemin des dames." Verzameld werk. Deel 5. Amsterdam: G.A. van Oorschot, 1949. Print.

Van Beusekom, Ansje. "Getting forgotten. Film critic Elisabeth de Roos and Dutch culture before World War II.” Researching women in silent cinema: New findings and perspectives. Eds. M. Dall'Asta, V. Duckett \& L. Tralli. Bologna: University of Bologna, 2013. 263-272. Print.

Van Boven, Erica. "Ver van de literatuur. Het schrijverschap van Ina Boudier-Bakker." Nederlandse Letterkunde 2:3 (1997): 242-257. Print.

Vandenbussche, Liselotte. "The Import of English Literature by Women Translators in Flanders, 1870-1914. A Comparative Survey." Crossing Cultures. Nineteenth-Century Anglophone Literature in the Low Countries. Eds. Tom Toremans and Walter Verschueren. Leuven: Leuven University Press, 2009. 137-154. Print.

Vandenbussche, Liselotte et al. "Virginie Loveling (1836-1923) as a Cultural Mediator: From Translating Klaus Groth to Manipulating Charles Darwin.” From Darwin to Weil. Women as Transmitters of Ideas. Ed. Petra Broomans. Groningen: Barkhuis, 2009. 47-71. Print.

Van Voorst, Sandra. "Deense literatuur bij Uitgeverij Contact 1960-1970." Jaarboek voor Nederlandse boekgeschiedenis. Leiden: Nederlandse Boekhistorische Vereniging, 1996. 145162. Print.

-. Weten wat er in de wereld te koop is. Vier Nederlandse uitgeverijen en hun vertaalde fondsen (1945-1970). Den Haag: SdU Uitgevers, 1997. Print.

Wolf, Michaela, “The Creation of a 'Room of One's Own': Feminist Translators as Mediators between Cultures and Genders." Gender, Sex and Translation. The Manipulation of Identities. Ed. José Santaemilia Ruiz. Manchester: St. Jerome, 2005. 15-25. Print.

Woods, Michelle. Kafka Translated: How Translators Have Shaped our Reading of Kafka. London: Bloomsbury, 2013. Print. 